\title{
Green Agriculture in West Sumatra: Farmer's Perceptions about Organic Farming
}

\author{
Rinex Wahyuni ${ }^{1}$, Gesit Thabrani ${ }^{*}$ \\ ${ }^{1}$ Universitas Negeri Padang, Padang, Indonesia , $₫$ rinexwahyuni@gmail.com \\ ${ }^{2}$ Universitas Negeri Padang, Padang, Indonesia , \gesitthabrani@gmail.com \\ *Corresponding Author
}

\begin{abstract}
This study aims to analyze the level of disability in printing PT. Padang Graindo Mediatama which focuses on producing newspapers using the six-sigma method. The analytical tools used in this study include check sheets, P-charts, fishbone, and pareto diagrams. Six sigma steps are defined, measure, analyze and improve. This research is expected to be able to improve the quality of prosduct based on zero defects or 3.4 disabilities per million opportunities by reducing the number of defects in the printing process. From the results of the analysis and research that has been done it turns out that there are still products that are blurry or opaque at $4.4 \%$. Based on the chart of the control chart it is known that there are six (6) points that are outside the control boundary which indicate that there are still high deviations in the production process. The number of defective products in PT. Padang Graindo Mediatama is at the sigma level of 3.21 with DPMO of 43,959 copies and it is known that factors that influence product quality include machinery, people, materials and methods.
\end{abstract}

Keywords: Quality Control, Six Sigma, DPMO

\section{Introduction}

The rapid industrial development requires companies to always produce products with good quality and in accordance with their functions and companies must also pay attention to the quality of these products so that they can be maintained (Hamzah, 2015).

Quality is very important for every company, including increasing the reputation of the company, being able to carry out production activities effectively and efficiently and key so that products can be known and trusted by the wider community.

According to Lupiyoadi (2014: 63) Quality is a combination of the characteristics and characteristics that determine the extent to which output can meet the requirements of customer needs, so customers determine and assess how far these characteristics and characteristics meet their needs. However, there are still products that do not meet standards or defects.

According to Sanjaya (2017) Defective products are products that are not in accordance with the specified quality standards and to overcome the defective products produced, producers can only prevent product defects.

One way that companies can do to improve quality is by controlling the quality of the product itself. According to Ratnadi \& Suprianto (2016) Quality control is the process used to guarantee the quality of a product or service.

One method used in quality control is the six-sigma method The Six Sigma method is a method for achieving company operating performance with only 3.4 defects for every one million activities or opportunities that aim to improve performance and find factors causing disability and reduce product defects. The higher the sigma target achieved, the better the company's process performance (Mada, 2018).

Based on data obtained from divorce PT. Padang Graindo Mediatama is known that the percentage of defective products reached $4.4 \%$ in 2018 . Of the total newspaper production of $7,189,066$ copies, blur or opaque newspapers reached 314,657 copies. With the following data: 
Table 1 Percentage of Disabled Products in 2018

\begin{tabular}{cllr}
\hline Number & Month & $\begin{array}{c}\text { Total } \\
\text { production } \\
\text { (copies) }\end{array}$ & $\begin{array}{c}\text { Number of } \\
\text { defective products } \\
\text { (copies) }\end{array}$ \\
\hline 1. & January & 638.200 & 26.342 \\
\hline 2. & February & 584.600 & 27.752 \\
\hline 3. & March & 631.050 & 23.321 \\
\hline 4. & April & 627.800 & 22.097 \\
\hline 5. & May & 602.450 & 26.048 \\
\hline 6. & June & 459.470 & 22.761 \\
\hline 7. & July & 644.000 & 33.046 \\
\hline 8. & August & 603.150 & 26.753 \\
\hline 9. & September & 591.240 & 28.077 \\
\hline 10. & October & 634.850 & 26.245 \\
\hline 11 & November & 581.456 & 23.937 \\
\hline 12. & December & 590.710 & 314.657 \\
\hline Total & & 7.189 .066 & \\
\hline
\end{tabular}

Source: Printing PT. Padang Graindo Mediatama

Printing PT. Padang Graindo Mediatama is required to periodically maintain and repair the products it produces in order to compete with similar manufacturing companies. The high percentage rate of defective products requires companies to continue to improve the quality of the products themselves.

Therefore, researchers want to further examine the root problems that exist in PT. Padang Graindo Mediatama in order to reduce the level of defective products in the company to achieve a zero defect rate (zero defect).

Heizer and Render (2017: 217) cite the quality definition put forward by the American Society for Quality. The overall characteristics and characteristics that are seen or not seen from the product are either goods or services that can meet the needs. According to Kotler (2007: 180) quality is the overall characteristics of the product in the form of goods and services that affect the ability to meet all consumer needs both verbally and not.

Quality Perspective

1. Transcedental Approach, according to this approach quality is seen as innate excellence, namely something that can be perceived or known, but is difficult to define, formulated or operationalized.

2. Product Based Approach, This, approach assumes that quality is an objective characteristic or attribute that can be quantified and can be measured.

3. User Based Approach, This, approach explains that quality depends on the person who judges it, so the product that best satisfies one's preferences is a high-quality product.

4. Manufacturing Based Approach, This, perspective is supply-based and focuses more on engineering and manufacturing practices, and defines quality as conformity or compatibility with requirements.

5. Value Based Approach, This approach views quality from aspects of value and price. By considering the trade-off between performance and price, quality is defined as affordable excellent.

According to Tjiptono (2008) is performance, durability, cobformace to specifications, features, reliability, esthetics, perceived quality and service quality. 
According to Putri (2015) Quality control is a technical and management activity carried out to achieve, maintain and improve the quality of a product and service and compare the results of measurements of output and input desired by the customer. Quality control is very important for companies because through quality control the company leaders can ascertain whether the product is feasible or not reaches the consumers and knows whether the product needs to be improved or not (Tampai \& Pondaag, 2017).

Tools for controlling quality include pareto diagrams, histograms, check sheets, causal diagrams and control maps.

Six sigma is a vision of quality improvement towards the target of 3.4 failure per million opportunities (DPMO) for each product transaction (goods and or services). Therefore, Six Sigma can be said as an effort made towards perfection (Sembiring, Kesatriya, 2011).

According to Beemaraj (2018) in the application of Six Sigma there are five stages called DMAIC (Define, Measure, Analyze, Improve, and Control).

\section{Conceptual Framework}

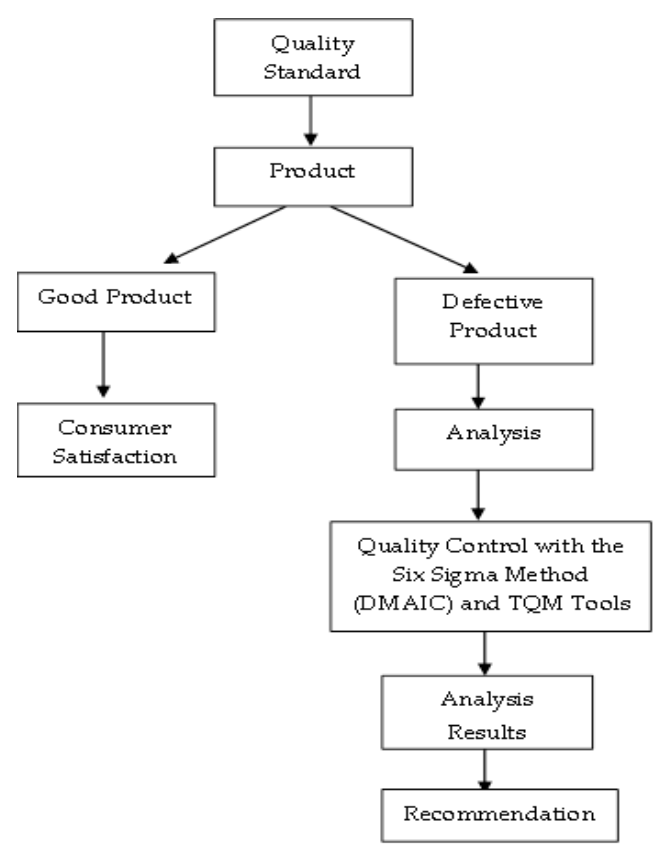

Figure 1 Conceptual Framework

\section{Methods}

This type of research is classified as descriptive research. This research begins with a field study of the actual conditions that occur in PT. Padang Graindo Mediatama. The sample collection technique is purposive sampling. The type of data used is primary and secondary data by means of interviews, observation and documentation.

Data analysis techniques from this study applying six sigma consists of several steps or stages commonly abbreviated as DMAIC. DMAIC is between Define, Measure, Analysis, Improve and Control.

At this stage the proportion of defects is determined to be the most significant cause of damage which is a source of production failure.

The measure stage is carried out through 2 stages with sampling for companies during 2018 as follows; Digram control P is used for attributes, namely the nature of goods based on the proportion of the number of events such as received or rejected due to the production process. This diagram can 
be arranged in several steps as follows; Population and sample collection, Check the characteristics by calculating the mean value.

The formula looks for the mean value: $p=\frac{\sum n p}{\sum n}$

information:

$\mathrm{n}$ : number of samples

$\mathrm{np}$ : number of disabilities

$\mathrm{p}$ : average disability proportion

Determine the limit of control over supervision carried out by setting the UCL (Upper Control Limit) and LCL (lower control limit / lower specification limit) values.

$$
U C L=p+3 \sqrt{\frac{p(1-p)}{n}} ; L C L=p-3 \sqrt{\frac{p(1-p)}{n}}
$$

information:

UCL : upper specification limit

LCL : lower specification limit

$\mathrm{p}$ : average disability proportion

$\mathrm{n}$ : number of samples

Analyzing sigma levels and defect for million company opportunities:

Calculate Defect per Unit (DPU)

$$
D P U=\frac{\text { Total Damage }}{\text { Total production }}
$$

Calculate DPMO first to determine the probability of the amount of damage.

$$
D P M O=\frac{\text { DPU X } 1000,000}{\text { damage problem }}
$$

is an examination of processes, facts and data to get an understanding of why a problem occurs and where there is an opportunity to make improvements. (R. Evans, James \& William M. Lindsay, 2007). Using a causal diagram, a causal diagram is used as a technical guideline of the operational functions of the production process to maximize the success values of a company's product quality at the same time by minimizing the risks of failure.

It is the stage of improving Six Sigma quality by taking measurements (see opportunities, damage, current capability processes), recommendations for improvement reviews, analyzing then corrective actions taken.

\section{Result and Discussion}

The world of publishing and printing are two fields that cannot be separated. The existence of Padang Ekspres, Posmetro Padang and Rakyat Sumbar Daily was inseparable from the existence of PT. Padang Graindo Mediatama is the largest newspaper printing company in West Sumatra. Started publishing the Padang Ekspres morning newspaper on 25 January 1999, at which time the newspaper for the West Sumatra market was taken by expedition car from Pekanbaru. A printing press was later established in Padang in August 1999 in Kotobaru-Banuaran, Lubuk Begalung District. During the 19 years this printing service served the needs of the publisher of the Padang Ekspres group and several weekly media outlets until finally the printing press then moved to Jl. Adinegoro No. 17A Lubuk Buaya Padang right on January 10, 2011. 


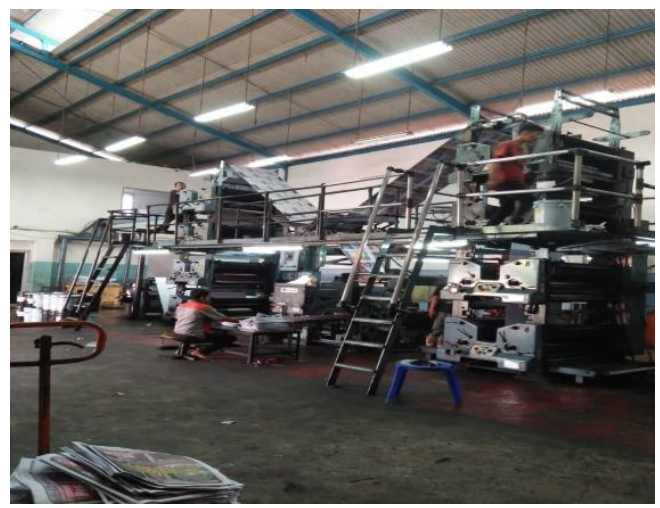

Figure 2 production process

Problems found at PT. Printing Padang Graindo Mediatama is a lack of thickness on the paper that makes colored images or photos printed in the newspaper newspaper blurred or blurred.

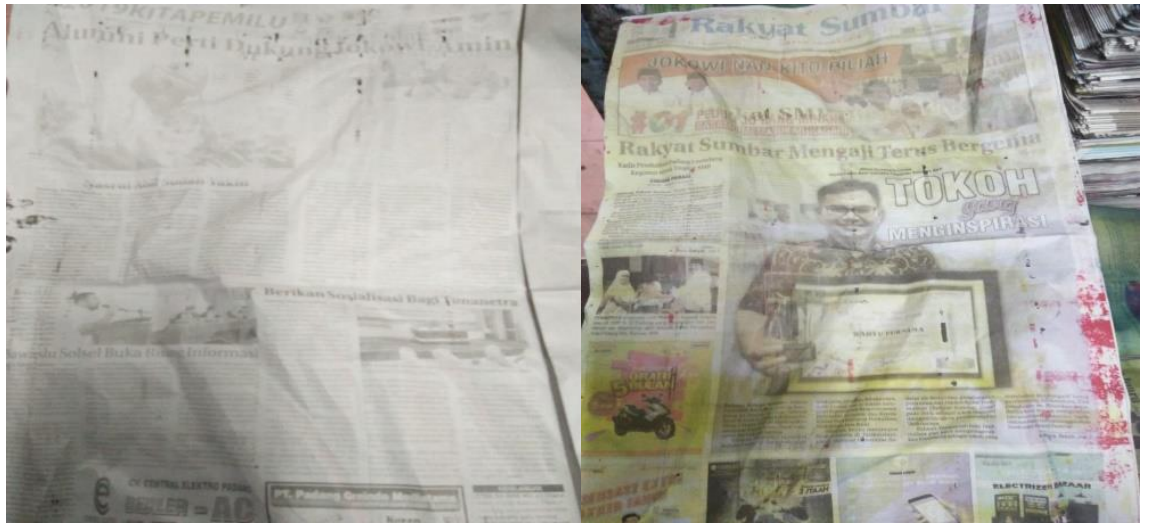

Figure 3 Newspaper Blurred

Table 2 Production and Disability Products in 2018

\begin{tabular}{clrrrr}
\hline Number & Month & $\begin{array}{l}\text { Total production } \\
\text { (eksemplar) }\end{array}$ & $\begin{array}{l}\text { Defective } \\
\text { product } \\
\text { (eksemplar) }\end{array}$ & $\begin{array}{l}\text { Percentage } \\
\text { defective } \\
\text { products (\%) }\end{array}$ & of \\
\hline $\mathbf{1 .}$ & January & 638.200 & 26.342 & 4,1 \\
\hline $\mathbf{2 .}$ & February & 584.600 & 27.752 & 4,7 \\
\hline $\mathbf{3 .}$ & March & 631.050 & 23.321 & 3,7 \\
\hline $\mathbf{4 .}$ & April & 627.800 & 22.097 & 3,5 \\
\hline $\mathbf{5 .}$ & May & 602.450 & 26.048 & 4,3 \\
\hline $\mathbf{6 .}$ & Juny & 459.470 & 22.761 & 5,0 \\
\hline $\mathbf{7 .}$ & July & 644.000 & 33.046 & 5,1 \\
\hline $\mathbf{8 .}$ & August & 603.150 & 26.753 & 4,4 \\
\hline $\mathbf{9 .}$ & September & 591.240 & 28.077 & 4,7 \\
\hline $\mathbf{1 0 .}$ & October & 634.850 & 26.245 & 4,1 \\
\hline $\mathbf{1 1}$ & November & 581.456 & 28.937 & 5,0 \\
\hline $\mathbf{1 2 .}$ & December & 590.710 & 23.371 & 4,0 \\
\hline Total & & $\mathbf{7 . 1 8 9 . 0 6 6}$ & $\mathbf{3 1 4 . 6 5 7}$ & $\mathbf{4} \mathbf{4}$ \\
\hline Average & & & & \\
\hline
\end{tabular}

Data is processed using Microsoft Excel

Based on the table above it can be seen that the percentage of defective or blurred products is $4.4 \%$ while the number is 314,657 copies. The number of defective products is a very large amount and results in high production costs. 
The stages of measurement or measurement carried out are measurements of the variables of each reject production and its types (Salomon, 2015). This stage is the second operational step in the six sigma quality improvement program.

Control diagram analysis (P-Chart)

Check the characteristics by calculating the mean value

$$
\mathrm{CL}=\frac{\sum n p}{\sum n}
$$

Calculating percentace of damage

$$
P=\frac{n p}{n}
$$

Determine the limit of control over supervision carried out by setting the UCL (Upper Control Limit)

$$
U C L=C L+3 \sqrt{\frac{C L(1-C L)}{n}}
$$

LCL (lower control limit / lower specification limit) values

$$
U C L=C L-3 \sqrt{\frac{C L(1-C L)}{n}}
$$

Table 3. Calculation of UCL, P, CL, and LCL values

\begin{tabular}{llllllll}
\hline Number & Month & $\mathbf{N}$ & $\mathbf{N p}$ & $\mathbf{P}$ & $\mathbf{U C L}$ & $\mathbf{C L}$ & LCL \\
& & & & & & & \\
\hline $\mathbf{1 .}$ & January & 638.200 & 26.342 & 0,041275 & 0,04377040 & 0,04376882 & 0,04376725 \\
\hline $\mathbf{2 .}$ & February & 584.600 & 27.752 & 0,047471 & 0,04377054 & 0,04376882 & 0,04376711 \\
\hline $\mathbf{3 .}$ & March & 631.050 & 23.321 & 0,036955 & 0,04377041 & 0,04376882 & 0,04376723 \\
\hline $\mathbf{4 .}$ & April & 627.800 & 22.097 & 0,035197 & 0,04377042 & 0,04376882 & 0,04376723 \\
\hline $\mathbf{5 .}$ & Mey & 602.450 & 26.048 & 0,043236 & 0,04377049 & 0,04376882 & 0,04376716 \\
\hline $\mathbf{6 .}$ & June & 459.470 & 22.761 & 0,049537 & 0,04377101 & 0,04376882 & 0,04376664 \\
\hline $\mathbf{7 .}$ & July & 644.000 & 33.046 & 0,051313 & 0,04377038 & 0,04376882 & 0,04376727 \\
\hline $\mathbf{8 .}$ & August & 603.150 & 26.753 & 0,044355 & 0,04377049 & 0,04376882 & 0,04376716 \\
\hline $\mathbf{9 .}$ & September & 591.240 & 28.077 & 0,047488 & 0,04377052 & 0,04376882 & 0,04376713 \\
\hline $\mathbf{1 0 .}$ & October & 634.850 & 26.245 & 0,041340 & 0,04377040 & 0,04376882 & 0,04376724 \\
\hline $\mathbf{1 1}$ & November & 581.456 & 28.937 & 0,049766 & 0,04377055 & 0,04376882 & 0,04376710 \\
\hline $\mathbf{1 2 .}$ & December & 590.710 & 23.371 & 0,039564 & 0,04377052 & 0,04376882 & 0,04376713 \\
\hline Total & & $\mathbf{7 . 1 8 9 . 0 6 6}$ & $\mathbf{3 1 4 . 6 5 7}$ & 0,043768 & & & \\
\hline
\end{tabular}

Data is processed using Microsoft Excel

From the results of the calculation above, then the $\mathrm{p}$ control chart can be created which can be seen in the following figure: 


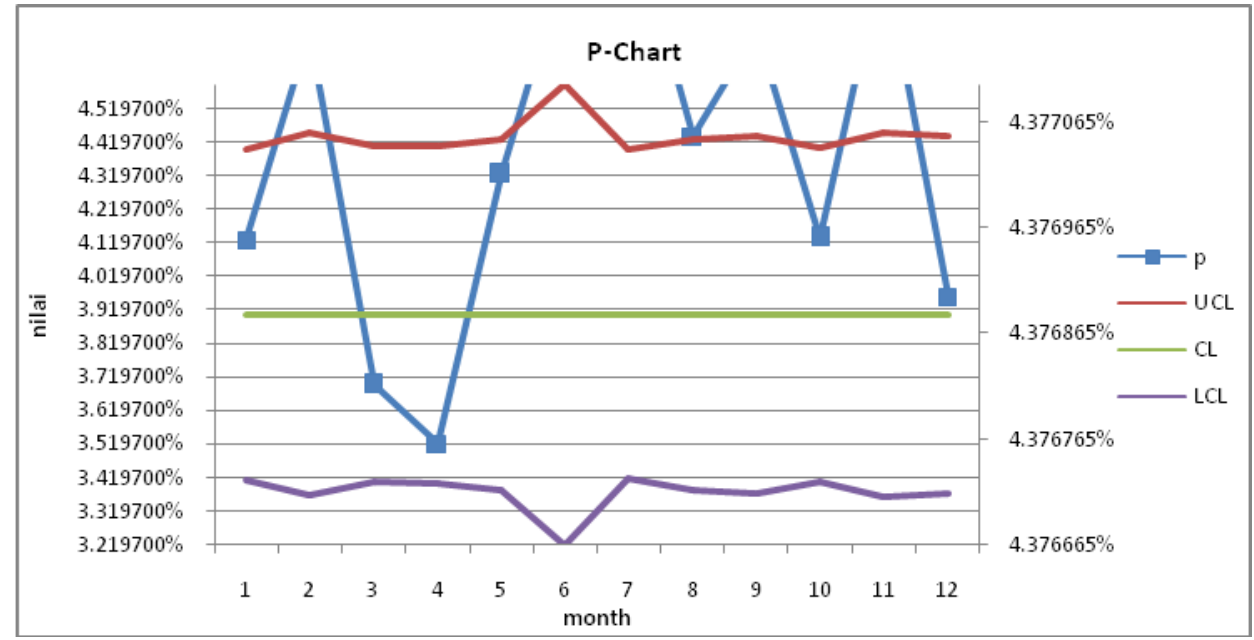

Figure 4 Graph of the Full Map of 2018

It is known that there are six (6) points that are within the control limit and six (6) other points are outside the control limit. This shows that the occurrence of high deviations and still very much needs to be carried out repairs in anticipation of the production process itself.

\section{Stage of Six Sigma and Defect Per Million Opportunities (DPMO) level measurement.}

Steps to measure the level of Six Sigma from the printing production of PT. Padang Graindo Mediatama, as follows:

Calculating DPU (Defect Per Unt)

$$
D P U=\frac{\text { Total damage }}{\text { Total production }}
$$

Calculating DPMO ( Defect Per Million Opportunities )

$$
\text { DPMO }=\frac{\text { DPU } X 1000.000}{\text { damage problem }}
$$

Convert the results of DPMO calculations with Six Sigma tables to get sigma results or use Microsoft Excel with formula $=$ NORMISV $(1-D P M O / 1,000,000)+1.5$

Table 4 Measuring Sigma Levels and Defect Per Million Opportunities (DPMO) in 2018

\begin{tabular}{llrrrrr} 
Num. & Month & Production & \multicolumn{1}{l}{$\begin{array}{l}\text { Defective } \\
\text { Product }\end{array}$} & DPU & DPMO & \multicolumn{1}{l}{$\begin{array}{l}\text { Sigma } \\
\text { value }\end{array}$} \\
\hline 1. & January & 638.200 & 26.342 & 0,041275462 & 41275,46224 & 3,23 \\
\hline 2. & February & 584.600 & 27.752 & 0,047471776 & 47471,77557 & 3,17 \\
\hline 3. & March & 631.050 & 23.321 & 0,036955867 & 36955,86721 & 3,29 \\
\hline 4. & April & 627.800 & 22.097 & 0,035197515 & 35197,51513 & 3,31 \\
\hline 5. & May & 602.450 & 26.048 & 0,043236783 & 43236,78314 & 3,21 \\
\hline 6. & Juny & 459.470 & 22.761 & 0,049537511 & 49537,51061 & 3,15 \\
\hline 7. & July & 644.000 & 33.046 & 0,051313665 & 51313,6646 & 3,13 \\
\hline 8. & August & 603.150 & 26.753 & 0,044355467 & 44355,46713 & 3,2 \\
\hline 9. & September & 591.240 & 28.077 & 0,04748833 & 47488,32961 & 3,17 \\
\hline 10. & October & 634.850 & 26.245 & 0,041340474 & 41340,47413 & 3,23 \\
\hline
\end{tabular}


Table Cont...

\begin{tabular}{lrrrrrr}
\hline $\mathbf{1 1}$ & November & 581.456 & 28.937 & 0,049766448 & 49766,44836 & 3,15 \\
\hline $\mathbf{1 2 .}$ & December & 590.710 & 23.371 & 0,039564253 & 39564,25319 & 3,26 \\
\hline Total & $\mathbf{7 . 1 8 9 . 0 6 6}$ & $\mathbf{3 1 4 . 6 5 7}$ & & & \\
\hline Average & & & 0,043958629 & 43958,62924 & $\mathbf{3 , 2 1}$ \\
\hline
\end{tabular}

Data is processed using Microsoft Excel

From the results of calculations in the table above, PT. Padang Graindo Mediatama has a sigma level of 3.21 with a possible damage of $43,958.6$ for one million production. this certainly results in a very large loss if it is not resolved as soon as possible due to increased production costs.

is an examination of processes, facts, and data to gain an understanding of why a problem occurs and where there is an opportunity to make improvements (Wisnubroto, 2015)

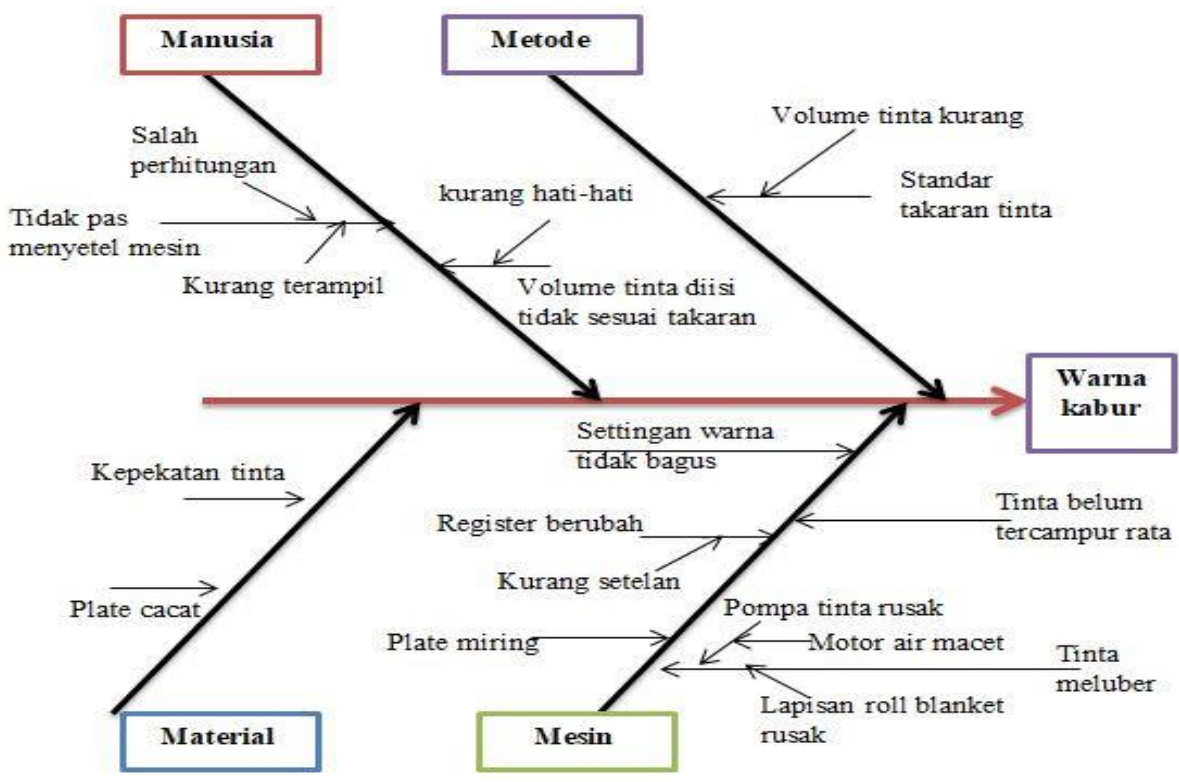

Figure 5 Causal diagram

In this step an action plan is implemented to implement the improvement of Six Sigma quality. The plan describes the allocation of resources as well as priorities or alternatives made.

Table 5 Proposed improvements for blurred color defects

\begin{tabular}{|c|c|c|c|}
\hline $\begin{array}{l}\text { Type of } \\
\text { factor }\end{array}$ & Causative factor & $\begin{array}{l}\text { Normal } \\
\text { standard }\end{array}$ & Proposed improvements \\
\hline Men & $\begin{array}{l}\text { 1. Lack of detail the } \\
\text { operator fills the ink } \\
\text { volume in the color } \\
\text { tank so that the } \\
\text { color does not } \\
\text { match the right } \\
\text { amount. } \\
\text { 2. The machine } \\
\text { operator is less } \\
\text { careful in adjusting }\end{array}$ & $\begin{array}{l}\text { 1. The ink must be } \\
\text { filled according to } \\
\text { the same dose or } \\
\text { percentage. } \\
\text { 2. The engine } \\
\text { settings must be } \\
\text { adjusted to the } \\
\text { engine's printing } \\
\text { capacity. }\end{array}$ & $\begin{array}{l}\text { Improve training so that } \\
\text { employees are more } \\
\text { skilled in carrying out } \\
\text { their duties. }\end{array}$ \\
\hline
\end{tabular}




the firmness of the
engine so that the
rotation can disrupt
the stability of the
engine. This is
caused by operators
who may not be
skilled / experienced
in making the right
settings and also
because of
miscalculations in
adjusting engine
tightness.

\begin{tabular}{|c|c|c|c|}
\hline Method & $\begin{array}{l}\text { There is no clear } \\
\text { standard or procedure } \\
\text { regarding } \\
\text { appropriate dose of ink. } \\
\text { Ink filling has no rules } \\
\text { so workers find it } \\
\text { difficult to fill quickly. }\end{array}$ & $\begin{array}{l}\text { Each ink is mixed at } \\
\text { the same dose or } \\
\text { percentage so that the } \\
\text { color is called neutral } \\
\text { gray }\end{array}$ & $\begin{array}{l}\text { Make a list or gray } \\
\text { formation curve or what is } \\
\text { often called the gray } \\
\text { balance to determine the } \\
\text { standard thickness of the } \\
\text { ink so that the printout is } \\
\text { in accordance with the } \\
\text { desired color. }\end{array}$ \\
\hline \multirow[t]{2}{*}{ Material } & $\begin{array}{l}\text { 1. Different levels of } \\
\text { ink density } \\
\text { 2. The presence of a } \\
\text { defective plate }\end{array}$ & $\begin{array}{l}\text { 1. Standard mix of ink } \\
\text { colors, usually the } \\
\text { combination of gray } \\
\text { balance used is: } \\
\text { a. for text using } \\
\text { solid colors ( } 100 \%) \\
\text { b. for images (dark } \\
\text { parts) a maximum } \\
\text { of } 90 \% \text { and } \\
\text { highlights (bright } \\
\text { parts) of at least } \\
10 \% \\
2 . \text { plate clean and } \\
\text { still wrapped neatly } \\
\text { in a box }\end{array}$ & $\begin{array}{l}\text { 1. Re-examine the raw } \\
\text { material received from } \\
\text { the supplier more } \\
\text { carefully and check } \\
\text { whether it meets the } \\
\text { specified specifications } \\
\text { or not. } \\
\text { 2. Separating damaged or } \\
\text { defective raw materials } \\
\text { with good quality raw } \\
\text { materials. }\end{array}$ \\
\hline & \multicolumn{3}{|l|}{ Table count... } \\
\hline Mesin & $\begin{array}{l}\text { 1. The ink is not } \\
\text { evenly mixed } \\
\text { 2. The ink melts } \\
\text { 3. Setting the color } \\
\text { percentage is not } \\
\text { good } \\
\text { 4. The register } \\
\text { changes } \\
\text { 5. Plate tilted }\end{array}$ & $\begin{array}{l}\text { 1. The ink must be } \\
\text { mixed at the } \\
\text { same dose so that } \\
\text { the results are } \\
\text { good } \\
\text { 2. Standard color } \\
\text { percentage } \\
\text { settings: } \\
\text { a. highlight point } \\
\text { (white dot): } \\
\text { C5 M3 Y3 }\end{array}$ & $\begin{array}{l}\text { 1. } \begin{array}{l}\text { Check } \\
\text { readiness carefully } \\
\text { before use and also } \\
\text { when finished }\end{array} \\
\text { 2. Perform maintenance } \\
\text { on a regular basis, not } \\
\text { only when the engine } \\
\text { is damaged } \\
\text { 3. provide engine parts } \\
\text { that replace the } \\
\text { components often }\end{array}$ \\
\hline
\end{tabular}




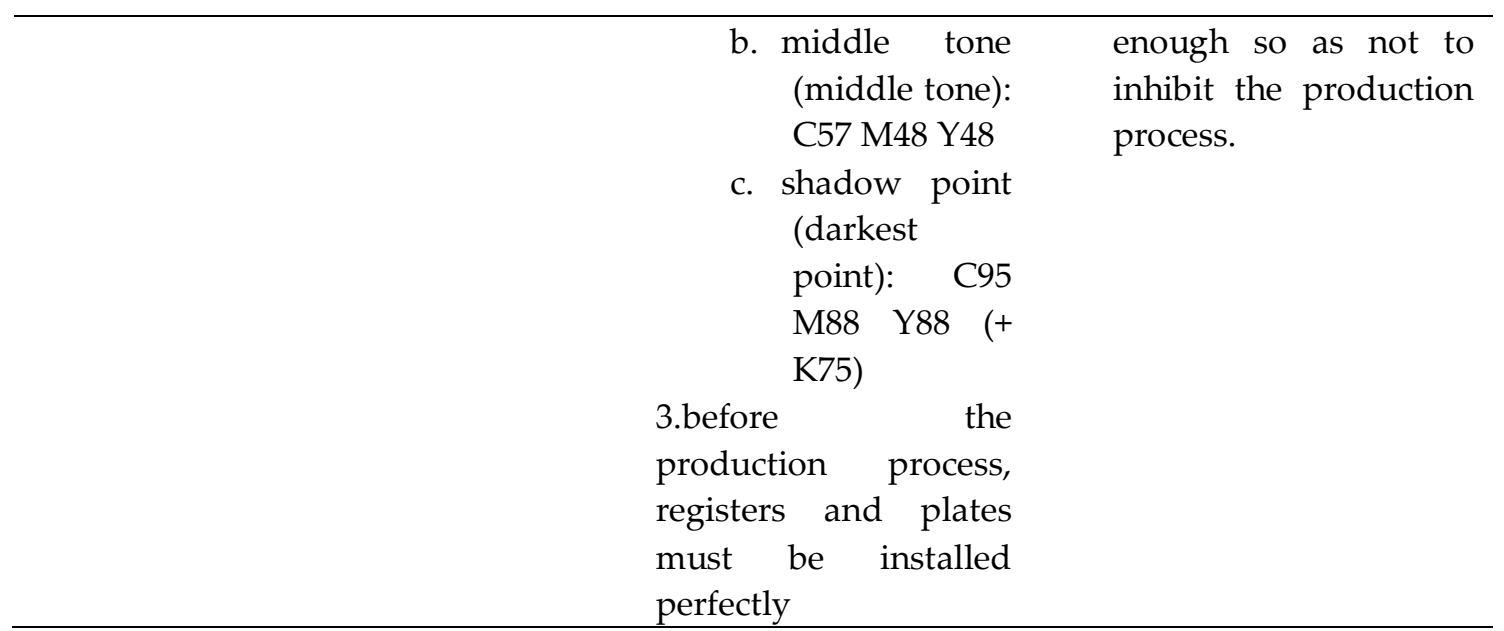

\section{Conclusions}

Based on production data obtained from PT. Padang Graindo Mediatama is known that the number of newspaper production in 2018 was 7,189,066 copies with the number of defective products occurring in the production amounting to 314,657 copies. While the average disability in each month of production is $4.4 \%$ and this value will cause losses for the company because it will increase production costs.

Types of damage that occur in printing production of PT. Padang Graindo Mediatama is caused by blurred colors of 314,657 copies.

1. Based on statistical aids with the control chart $p$ in controlling the product, it can be identified that the quality of the product is outside the proper control limit. There are six (6) points that are outside the control limit which can be interpreted that the production process is in an uncontrolled state or is still experiencing irregularities.

2. Based on the calculation of the sigma level PT. Padang Graindo Mediatama has a sigma level of 3.21 with a probability of damage of 43958,62924 or rounded up to 43,959 for a million production (DPMO).

3. From the causal diagram analysis, it can be seen that the disability that occurs is caused by several factors, including machine factors, human factors, material factors and method factors.

Printing PT. Padang Graindo Mediatama needs to use the six sigma method to find out the types of damage that often occur and what factors are the cause. So that PT. Padang Graindo Mediatama can immediately take preventive measures to reduce the occurrence of defective products.

Improvement suggestions in order to reduce defective products include:

1. Human factor

Forming a part of work whose task is to supervise and double-check employee performance to reduce errors in adjustment and filling in ink caused by human error. Improve training so that employees are more skilled in carrying out their duties.

2. Method Factor

Making a list or curve of gray formation or what is achieved is often called gray balance to determine the standard thickness of the ink so that the printed results that match the desired color.

3. Material Factor

Check the raw material received from the supplier more thoroughly and check whether it meets the specified specifications or not. Separating damaged or defective raw materials with good quality raw materials.

4. Machine Factor

Checking machine readiness carefully before use and also when finished. Routine maintenance of the machine, not only when the engine is damaged and provide engine parts that replace parts frequently enough to not hinder the production process. 


\section{References}

Adianto, hamzah asadullah dan hari. (2015). Jumlah produk cacat tekstil kain katun menggunakan metode six sigma pada $\mathrm{pt.}$ ssp *, 03(03), 148-159.

Baum, Feigen. (2012). Kendali Mutu Terpadu (alih bahasa). Jakarta: Erlangga

Beemaraj, R. K. (2018). Six Sigma Concept and Dmaic Implementation. International Journal of Business Management \& Research (IJBMR), 3(2), 111-114.

Evans, J.R. dan William M. Lindsay. 2007. An Introduction to Six Sigma and Process Improvement. Jakarta : Salemba Empat

Gaspersz, Vincent. (2011). Lean Six Sigma for Manufacturing and Service Industries. Bogor: Penerbit Vinchristo Publication.

Heizer, Jay, Barry Render, Chuck Munson. (2017). Operations Management:Sustainability and Chain Management. America: Pearson Education, INC.

Kerzner, H. (2009). Project Management: A Systems Approach to Planning,Scheduling, and Controlling (10 th ed.). Hoboken, New Jersey: John Wiley \& Sons, Inc.

Kotler, Philip. (2007). Manajemen Pemasaran. Jilid 2, Edisi 12. PT Indeks: New Jersey.

Lupiyoadi, Rambat. 2014. Manajemen Pemasaran Jasa Berbasis Kompetensi. Edisi ke-3. Jakarta: Salemba Empat.

Mada, M. S. N. dan E. (2018). Metode Six Sigma untuk Mengendalikan Kualitas Produk Surat Kabar di PT X Margie. Jurnal Ilmiah Teknik Industri Prima, 2(1), 15-21.

Montgomery, Douglas C. (2013). Introduction to Statistical Quality Control 7th edition. United State of America: John Wiley and Soon.

Neyestani, B. (2017). Seven Basic Tools of Quality Control: The Appropriate Techniques for Solving Quality Problems in the Organizations. MPRA, 07(08).

Putri, S. A. (2015). Analisis Pengendalian Kualitas Produk Dengan Menggunakan Metode Statistical Processing Control PT Sumiati Ekspor Internasional. Jurnal Manajemen Operasional.

Ratnadi, \& Suprianto, E. (2016). Pengendalian Kualitas Produksi Menggunakan Alat Bantu Statistik (Seven Tools) Dalam Upaya Menekan Tingkat Kerusakan Produk. Program Studi Teknik \& Manajemen Pembekalan Fakultas Teknik Universitas Nurtanio Bandung, 6(2), 10-18.

Reppi, J. M. (2015). Analisis Pengaruh Persepsi Kualitas, Motivasi Dan Sikap Konsumen Terhadap Keputusan Pembelian Ponsel Iphone Pada Pusat Perbelanjaan Itc Manado. Jurnal Berkala Ilmiah Efisiensi, 15(828-838), 1.

Sanjaya, W. U. N. (2017). Air Mineral Dalam Upaya Perbaikan Dmaic Six Sigma, 3(1), 87-101.

Shigemori, H. (2013). Quality and operation management system for steel products through multivariate statistical process control. Lecture Notes in Engineering and Computer Science, 1 LNECS, 305310.

Tampai, Y. S., \& Pondaag, J. S. B. S. J. J. (2017). Implementation Of Quality Control On Clean Water Production In Pt. Air Manado. Jurnal EMBA, 5(2), 1644-1652.

Tjiptono, Fandy. (2008).Strategi Pemasaran. Edisi 3. ANDI: Yogyakarta

Wisnubroto, P. (2015). Analisis Kaizen Serta New Seven Tools Sebagai Usaha Pengurangan Kecacatan Produk. Jurnal Teknik Industri IST Akprind, 8(1), 65-74 